\title{
Renal Pelvis and Ureter Cancer pN1 TNM
} Finding $v 7$

National Cancer Institute

\section{Source}

National Cancer Institute. Renal Pelvis and Ureter Cancer pN1 TNM Finding v7. NCI

Thesaurus. Code C89318.

Renal pelvis and ureter cancer with metastasis in a single lymph node, $2 \mathrm{~cm}$ or less in greatest dimension. (from AJCC 7th Ed.) 